\title{
Changes in the Activities of Protective Enzymes Induced by Mepiquat Chloride (DPC) in Cotton to Defend Against Aphids
}

\author{
Quancheng Zhang \\ Shihezi University \\ Xiaoxia Deng \\ Shihezi University \\ Jungang Wang ( $\sim$ wangjungang98@163.com) \\ Shihezi University
}

\author{
Research Article \\ Keywords: DPC, cotton, aphids, protective enzymes, detoxifying enzymes, resistance ability \\ Posted Date: December 21st, 2021 \\ DOI: https://doi.org/10.21203/rs.3.rs-1177093/v1 \\ License: (c) (i) This work is licensed under a Creative Commons Attribution 4.0 International License. Read Full License
}




\section{Abstract}

Background: Mepiquat chloride (DPC) enhances the resistance of cotton plants, and it is widely used as a growth regulator. DPC can stimulate photosynthesis, stabilize the structure of cotton leaves, and affect population reproduction and energy substances in cotton aphids, but interactions between DPC and cotton aphids remain unclear. In this study, we analyzed the physiological responses of cotton to DPC, and the toxicity of DPC toward cotton aphids, before and after feeding, to explore the DPC-induced defense mechanism against cotton aphids.

Results: Measurements of protective enzyme activity in cotton showed that the soluble protein contents, peroxidase (POD) activity, and catalase (CAT) activity in cotton treated with different concentrations of DPC were higher than in the control. Superoxide dismutase (SOD) activity was higher than that of controls when the concentration of DPC was $<0.1 \mathrm{~g} / \mathrm{L}$. Under aphid stress, POD activity of cotton treated with a low insect population density was significantly lower than that of controls, but the reverse was true for cotton treated with a high insect population density, and SOD activity was positively correlated with population density. The activities of detoxification enzymes in field and laboratory experiments showed that DPC promoted the specific activity of glutathione S-transferase (GST) in cotton aphids, while the specific activities of carboxylesterase and acetylcholinesterase were decreased.

Conclusions: DPC enhanced the resistance of cotton by increasing the activity of protective enzymes. It also had a toxic effect on cotton aphids by increasing GST activity (the main DPC target) and lowering carboxylesterase and acetylcholinesterase activities. DPC increased the soluble protein content and SOD activity in cotton under aphid stress, and thereby enhanced tolerance to cotton aphids.

\section{Background}

As an important economic crop in many places in the world, cotton has an indeterminate growth habit. As long as the environmental conditions are suitable, it can continue squaring, flowering, and producing bolls (Chen and Dong, 2016), which leads to a balance between reproductive growth and vegetative growth (Mao et al., 2018). An excessive nutrient supply leads to poor reproductive organ development, which in turn results in low yield and poor fiber quality (Yan et al., 2019). Therefore, in the cultivation and planting of cotton, the grower should not only focus on the management of water and fertilizer in the field (Zhao and Oosterhuis, 2000; Schaefer et al., 2017), but should also consider the use of exogenous plant hormones for chemical regulation (Kaur et al., 2021) for reasonable control of cotton growth and development. This will determine the shape of the ideal plant type (Hussain et al., 2020) by reducing plant height (Wang et al., 2019), shorten the main stem and fruiting branch internodes (Wang et al., 2014; Zhang et al., 2020), improve light transmittance, reduce boll shedding (Gao et al., 2019), and promote boll opening (Liao et al., 2021) to improve economic yield (Tung et al., 2019; Leal et al., 2020).

Mepiquat chloride (1,1-dimethylpiperidium chloride; DPC) is a synthetic plant hormone that is widely used as a growth retardant in cotton (Nóbrega et al., 1999; Rademacher, 2000; Zhao and Oosterhuis, 2000; Nuti et al., 2006; Wang et al., 2014). DPC inhibits gibberellin synthesis in plants (Qiu et al., 2019; Zhang et al., 2020) and can control cotton vegetative growth, reduce boll shedding, and promote boll development and root growth (Wu et al., 2019; Liang et al., 2020; Zhang et al., 2020). DPC has also been shown to improve cell membrane stability and stress tolerance in plants (Wang et al., $2019 ; 2020$ ). Our previous research results also helped to explain the action of DPC. Treatment with appropriate concentrations of DPC can increase the content of free proline and soluble protein in cotton leaves, reduce the malondialdehyde (MDA) content, increase the osmotic pressure resistance of cotton cells, promote stress resistance, and improve drought resistance in cotton (Zhou et al., 2010; Deng et al., 2013). By increasing leaf wax deposition and chlorophyll content, the photosynthetic rate of cotton leaves was effectively improved (Cui and Wang, 2017). In addition, DPC induces the production of phenolic secondary metabolites in cotton leaves, and the increase in lignin, total phenols, tannins, flavonoids, and related compounds can enhance stress resistance in cotton (Cui et al., 2017).

Science-based, rational application of DPC can not only promote high yields in cotton, but can also enhance the defense response of host plants to pests (Zhou et al., 2019). Studies have shown that DPC has a negative effect on the growth and development of the cotton pests Helicoverpa armigera (Hübner) (cotton bollworm) and Tetranychus cinnabarinus (Boisduval) (carmine spider mite), and with increasing DPC concentrations, the body weights of $H$. armigera larvae reared in the laboratory decreased in an 'S' curve (sigmoid function), which may be due to the large increase in the amount of gossypol produced by the cotton plants (Qu et al., 2008). At the same time, the use of DPC can block feeding in $T$. cinnabarinus, leading to reproductive decline (Shu et al., 1996). DPC has a 'Dual Regulation Effect' on cotton growth and development, which makes it a key chemical regulator in the cotton planting industry (Ibrahim, 2009).

The cotton aphid, Aphis gossypii (Glover), is the main pest of cotton. A. gossypii can cause damage throughout the cotton growth period, which can cause wilting and deformity in cotton seedlings (Hullé et al., 2020) The honeydew secreted by cotton aphids also affects photosynthesis and fiber quality in cotton, and can seriously endanger cotton production (Jacobson and Croft, 1998). In the process of artificial control of $A$. gossypii, the cotton aphids are forced to participate in this process. We have previously found that cotton aphids need to consume energy reserves in the form of body fat to cope with the stress associated with exposure to DPC. At the same time, carbohydrates, free amino acids, and protein energy sources begin to accumulate in cotton aphids to maintain their normal life activities (Cui et al., 2018). In response to DPC stimulation, the specific activities of SOD, POD, and CAT increase rapidly (Zhong et al., 2017). With increases in DPC treatment time, adult longevity and reproductive capacity in cotton aphids decreased gradually, and DPC had a good inhibitory effect on the cotton aphid population ( Zhou et al., 2011). Previous studies only focused on the relationships between DPC and cotton aphids, DPC and cotton, and cotton and cotton aphids. However, in field applications, we often faced the 
DPC-cotton-cotton aphid interaction. Therefore, this study focused on the physiological response of cotton to cotton aphids before and after feeding on cotton and the mechanism of DPC toxicity on cotton aphids, and will provide a theoretical basis for better application of DPC to cotton in the field.

\section{Methods \\ Experiment site and materials.}

The experimental field was in the Test Site of Shihezi University $\left(\mathrm{E} 86^{\circ}, \mathrm{N} 44^{\circ}\right)$. The cotton variety used in this field experiment was 'New Upland Early Maturity 44'. DPC was purchased from Anyang Xiaokang Pesticide Co., Ltd (Anyang city, China).

The cotton aphids came from an artificial breeding population in the insect greenhouse of Shihezi University. Over 30 generations of aphids have been subcultured on cotton. Feeding temperature was $26 \pm 1^{\circ} \mathrm{C}$, relative humidity was $60-80 \%$, and the light intensity was 9,000 Ix with a $14 \mathrm{~h}$ light: 10 h dark photoperiod.

\section{Determination of protective enzyme activity in cotton induced by DPC treatment.}

At the flowering and boll-forming periods, cotton plants were sprayed with DPC at concentrations of $0,0.05,0.1,0.25,0.5$, and $1.0 \mathrm{~g} / \mathrm{L}(30 \mathrm{~kg}$ water $/ 667 \mathrm{~m}^{2}$ ) using a completely randomized block design. The changes in soluble protein contents and POD, SOD, and CAT activities in cotton were determined at $5,10,15$, and 20 days after application. There were three replicates per treatment.

\section{Determination of detoxifying enzyme activity in aphids following DPC treatments in the field.}

During flowering and boll-forming periods, cotton plants exhibiting were selected randomly. The plants were infested with 300 test aphids on the top three leaves and covered with gauze $(0.5 \mathrm{~m} * 1.2 \mathrm{~m}, 120 \mathrm{mesh})$. One day after infestation, the plants were sprayed with different concentrations $(0$, $0.05,0.1,0.25,0.5,1 \mathrm{~g} / \mathrm{L}$ ) of DPC. At 5,10 , and 15 days after application, 100 wingless adults were selected to determine the specific activities of acetylcholinesterase, carboxylesterase, and GST. Each treatment was repeated three times.

\section{Determination of detoxifying enzyme activity by DPC leaf immersion treatment.}

Cotton leaves soaked in different concentrations of DPC were placed on their abaxial surfaces in $10 \mathrm{~cm}$ petri dishes containing $5 \mathrm{~mL}$ agar liquid, and 30 wingless aphids were collected with a brush and placed on the cotton leaves. Defatted cotton wool was used to surround the cotton leaves to prevent aphids from escaping. After five days of feeding, 100 aphids were selected to determine the specific activities of acetylcholinesterase, carboxylesterase, and GST. There were 18 dishes per treatment, and each treatment was repeated three times.

\section{Determination of cotton protective enzyme activity by DPC treatment under aphid stress.}

Based on the degree of damage due to cotton aphid feeding, the population density of cotton was divided into 0 aphid, low population density (100300 aphids), and high population density (>500 aphids). After selecting the appropriate cotton plant marker, cotton plants were covered with gauze (0.5 m¹.2 m, 120 mesh), and sprayed with different concentrations of DPC. The changes in soluble protein contents and POD, SOD, and CAT activities in cotton were measured at $5,10,15$, and 20 days after DPC application. Each treatment was repeated three times.

\section{Determination of protective/detoxifying enzyme activity.}

Soluble protein contents were determined by the G-250 dye colorimetric method (Bradford, 1976). Peroxidase (POD) activity was determined by the guaiacol method. The activity of superoxide dismutase (SOD) was determined by the inhibition photoreduction method, where $50 \%$ of the enzyme amount inhibiting NBT reduction is defined as a unit of enzyme activity. CAT activity was determined by the UV absorption method. For detailed descriptions of these methods of determination, refer to the publication of Li (2009). The specific activities of acetylcholinesterase, carboxylesterase, and GST were determined as described by Wang (2011).

\section{Statistical analysis.}

Microsoft Excel 2010 was used for data processing and plotting. SPSS 19.0 data processing software was used for statistics, and the mean values and standard errors were calculated. Duncan's new multiple range test method was used to test the significance between the differences in the 
means.

\section{Results \\ Effect of DPC dosage on protective enzyme activities in cotton during the flowering and boll-forming period.}

In this experiment, the soluble protein content and the POD and CAT activities in cotton for each DPC concentration treatment were higher than those of the control. At 20 days after treatment, the soluble protein content, CAT activity, and POD activity of cotton plants sprayed with $0.25 \mathrm{~g} / \mathrm{L}$ DPC were significantly higher than in the control by 2.60-, 2.33-, and 2.78-fold $(p<0.05)$ (Figures 1A, 1C, and 1D). When the DPC concentration was less than or equal to $0.5 \mathrm{~g} / \mathrm{L}$, the SOD activity decreased as the DPC concentration increased, after which it increased. The SOD activity in the $0.5 \mathrm{~g} / \mathrm{L}$ DPC treatment was the lowest, and it was significantly lower than the control by $13.13 \%(p<0.05)$ (Figure 1B).

However, at 20 days after DPC treatment, the SOD and CAT activities in cotton showed the opposite trend compared with the early stage of the experiment (SOD activity increased and CAT activity decreased), which may be due to the gradual decrease in DPC efficacy over time (Figures 1B and 1D). Therefore, we conclude that spraying with DPC at a concentration of $0.25 \mathrm{~g} / \mathrm{L}$ during the flowering and boll-forming period can most enhance stress resistance in cotton, and DPC can be applied again 20 days later to regulate cotton growth.

\section{Effect of DPC treatment on detoxifying enzyme activities in cotton aphids.}

The specific activity of GST in cotton aphids was increased by spraying the plants with DPC in the field, and GST activity was positively correlated with DPC concentration. With increasing treatment duration, GST activity in cotton aphids decreased, which may be due to enhanced adaptation of cotton aphids to DPC (Figure 2A). However, the activities of carboxylesterase and acetylcholinesterase decreased with increasing DPC concentration (Figures 2B and 2C).

The leaf dipping test showed that when the DPC concentration was $\leq 0.25 \mathrm{~g} / \mathrm{L}$, the GST activity in cotton aphids was significantly higher than in the control and the $0.05 \mathrm{~g} / \mathrm{L}$ and $0.1 \mathrm{~g} / \mathrm{L}$ DPC treatments. When the DPC concentration was $>0.25 \mathrm{~g} / \mathrm{L}$, the specific activity of the enzyme decreased as the DPC concentration increased, although it remained significantly higher than in the control. Therefore, it appears that DPC concentration $\leq 0.25 \mathrm{~g} / \mathrm{L}$ has a certain toxicity to cotton aphids, and that the sensitivity of cotton aphids to DPC decreased at the two higher concentrations used in the experiment (Figure 3A). When the DPC concentration was $\leq 0.5 \mathrm{~g} / \mathrm{L}$, the specific activity of carboxylesterase decreased with increasing DPC concentration (Figure $3 \mathrm{~B}$ ). The specific activity of acetylcholinesterase decreased significantly as the DPC concentration increased from $0.05 \mathrm{~g} / \mathrm{L}$ to 1 $\mathrm{g} / \mathrm{L}$ (Figure 3C).

DPC mainly affects the GST activity in cotton aphids, but not the other detoxification enzymes assayed in this study. Therefore, even though DPC acts as a plant growth regulator, when the DPC concentration $<0.5 \mathrm{~g} / \mathrm{L}$, the growth of cotton aphids will also have a certain impact, and treatment with higher DPC concentrations will reduce the sensitivity of cotton aphids.

\section{Effects of DPC on protective enzyme activities in cotton under aphid stress during the flowering and boll-forming period.}

After 5 days of DPC treatment, there was no significant difference in cotton protein content among different treatments. Under low population density stress, the cotton protein content of the $0.25 \mathrm{~g} / \mathrm{L}$ DPC treatment was the lowest, significantly lower $(5.57 \%)$ than that of controls $(P<0.05)$. Under high population density stress, the protein content of cotton treated with $0.1 \mathrm{~g} / \mathrm{L}$ DPC was the highest, significantly higher (3.93\%) than that of controls $(P<0.05)$. Under the same concentration of DPC, the protein content of cotton without aphids and under low population density feeding stress first decreased then increased. The protein content of $0.1 \mathrm{~g} / \mathrm{L}$ and $0.25 \mathrm{~g} / \mathrm{L}$ DPC treatments reached minimum values at the same time, which were 722.68 $\mathrm{mg} / \mathrm{g}$ and $666.28 \mathrm{mg} / \mathrm{g}$, respectively. The protein content of cotton under high population density stress displayed the opposite trend, and reached a maximum of $773.08 \mathrm{mg} / \mathrm{g}$ when treated with $0.1 \mathrm{~g} / \mathrm{L} \mathrm{DPC}$ (Table 1). 
Table 1

Effects of DPC treatment on protein content in cotton leaves under aphid feeding stress. Unit, mg/g. Black lower-case letters for the same time and the same population density indicate significant differences between the different concentration DPC treatments. Red letters in the same column indicate the significant differences between treatments with different aphid population densities at the same time and the same DPC concentration. There were no significant differences for treatments with the same letter $(p>0.05)$, and there were significant differences between treatments with different letters $(p<0.05)$. Low density, $100-300$ aphids; High density, $>500$ aphids.

\begin{tabular}{|c|c|c|c|c|c|c|c|}
\hline \multirow{2}{*}{$\begin{array}{l}\text { DPC treatment (days after } \\
\text { spraying) }\end{array}$} & \multirow{2}{*}{$\begin{array}{l}\text { Aphid } \\
\text { density }\end{array}$} & \multicolumn{6}{|c|}{ DPC concentration $(\mathrm{g} / \mathrm{L})$} \\
\hline & & 0 & 0.05 & 0.1 & 0.25 & 0.5 & 1 \\
\hline \multirow[t]{3}{*}{$5 d$} & 0 & $\begin{array}{l}749.61 \pm 3.14 \\
\text { a a }\end{array}$ & $\begin{array}{l}761.88 \pm 1.74 \\
\text { a a }\end{array}$ & $\begin{array}{l}722.68 \pm 16.35 \\
\mathrm{~b} \mathrm{~b}\end{array}$ & $\begin{array}{l}762.55 \pm 5.43 \\
\text { a a }\end{array}$ & $\begin{array}{l}758.28 \pm 6.12 \\
\text { a a }\end{array}$ & $\begin{array}{l}737.35 \pm 0.35 \\
\mathrm{ab} a\end{array}$ \\
\hline & $\begin{array}{l}\text { Low } \\
\text { density }\end{array}$ & $\begin{array}{l}705.61 \pm 2.89 \\
\mathrm{~d} \mathrm{~b}\end{array}$ & $\begin{array}{l}754.95 \pm 2.89 \\
\mathrm{ab} \mathrm{a}\end{array}$ & $\begin{array}{l}729.88 \pm 2.08 \\
\mathrm{c} \mathrm{b}\end{array}$ & $\begin{array}{l}666.28 \pm 1.67 \mathrm{e} \\
\mathrm{b}\end{array}$ & $\begin{array}{l}763.88 \pm 4.41 \\
\mathrm{a} \mathrm{a}\end{array}$ & $\begin{array}{l}746.81 \pm 7.59 \\
\text { b a }\end{array}$ \\
\hline & $\begin{array}{l}\text { High } \\
\text { density }\end{array}$ & $\begin{array}{l}743.88 \pm 3.59 \\
\text { b a }\end{array}$ & $\begin{array}{l}728.28 \pm 9.71 \\
\text { bc b }\end{array}$ & $\begin{array}{l}773.08 \pm 5.66 \\
\text { a a }\end{array}$ & $\begin{array}{l}769.88 \pm 2.43 \\
\text { a a }\end{array}$ & $\begin{array}{l}723.75 \pm 3.93 \\
\mathrm{~cd} \mathrm{~b}\end{array}$ & $\begin{array}{l}711.08 \pm 2.66 \\
d b\end{array}$ \\
\hline \multirow[t]{3}{*}{$10 \mathrm{~d}$} & 0 & $\begin{array}{l}315.75 \pm 2.31 \\
d b\end{array}$ & $\begin{array}{l}427.88 \pm 21.25 \\
\text { b b }\end{array}$ & $\begin{array}{l}358.82 \pm 1.5 \\
\mathrm{~cd} \mathrm{c}\end{array}$ & $\begin{array}{l}395.48 \pm 39.04 \\
\text { bc b }\end{array}$ & $\begin{array}{l}758.55 \pm 7.39 \\
\text { a b }\end{array}$ & $\begin{array}{l}758.68 \pm 2.89 \\
\text { a a }\end{array}$ \\
\hline & $\begin{array}{l}\text { Low } \\
\text { density }\end{array}$ & $\begin{array}{l}18.28 \pm 1.29 \mathrm{e} \\
\mathrm{b}\end{array}$ & $\begin{array}{l}414.15 \pm 2.22 \\
d b\end{array}$ & $\begin{array}{l}766.01 \pm 3.24 \\
\text { b a }\end{array}$ & $\begin{array}{l}723.08 \pm 18.24 \\
\text { с a }\end{array}$ & $\begin{array}{l}811.08 \pm 16.19 \\
\text { a a }\end{array}$ & $\begin{array}{l}692.01 \pm 17.55 \\
\text { c b }\end{array}$ \\
\hline & $\begin{array}{l}\text { High } \\
\text { density }\end{array}$ & $\begin{array}{l}623.48 \pm 25.30 \\
\mathrm{~d} a\end{array}$ & $\begin{array}{l}721.75 \pm 2.08 \\
\text { bc a }\end{array}$ & $\begin{array}{l}739.35 \pm 6.35 \\
\text { b b }\end{array}$ & $\begin{array}{l}702.95 \pm 1.96 \mathrm{c} \\
\mathrm{a}\end{array}$ & $\begin{array}{l}754.15 \pm 2.89 \\
\text { ab b }\end{array}$ & $\begin{array}{l}778.28 \pm 2.54 \\
\text { a a }\end{array}$ \\
\hline \multirow[t]{3}{*}{$15 d$} & 0 & $\begin{array}{l}327.88 \pm 2.20 \\
\text { e c }\end{array}$ & $\begin{array}{l}527.08 \pm 2.23 \\
\mathrm{c} \mathrm{b}\end{array}$ & $\begin{array}{l}649.75 \pm 8.20 \\
\text { b b }\end{array}$ & $\begin{array}{l}445.48 \pm 25.77 \\
\mathrm{~d} \mathrm{c}\end{array}$ & $\begin{array}{l}686.95 \pm 1.04 \\
\text { a a }\end{array}$ & $\begin{array}{l}692.68 \pm 0.46 \\
\text { a a }\end{array}$ \\
\hline & $\begin{array}{l}\text { Low } \\
\text { density }\end{array}$ & $\begin{array}{l}535.48 \pm 4.54 \\
\mathrm{c} \mathrm{b}\end{array}$ & $\begin{array}{l}527.08 \pm 32.79 \\
\mathrm{c} \mathrm{b}\end{array}$ & $\begin{array}{l}708.68 \pm 6.25 \\
\text { a a }\end{array}$ & $\begin{array}{l}702.41 \pm 4.75 \\
\text { a a }\end{array}$ & $\begin{array}{l}646.68 \pm 16.75 \\
\text { b a }\end{array}$ & $\begin{array}{l}670.28 \pm 3.49 \\
\text { ab b }\end{array}$ \\
\hline & $\begin{array}{l}\text { High } \\
\text { density }\end{array}$ & $\begin{array}{l}690.95 \pm 3.61 \\
\text { a a }\end{array}$ & $\begin{array}{l}689.88 \pm 0.92 \\
\text { a a }\end{array}$ & $\begin{array}{l}706.41 \pm 2.15 \\
\text { a a }\end{array}$ & $\begin{array}{l}500.81 \pm 5.20 \\
\text { b b }\end{array}$ & $\begin{array}{l}694.95 \pm 24.94 \\
\text { a a }\end{array}$ & $\begin{array}{l}703.08 \pm 4.41 \\
\text { a a }\end{array}$ \\
\hline \multirow[t]{3}{*}{$20 \mathrm{~d}$} & 0 & $\begin{array}{l}149.75 \pm 2.45 \\
\text { e c }\end{array}$ & $\begin{array}{l}458.41 \pm 6.58 \\
\mathrm{c} \mathrm{a}\end{array}$ & $\begin{array}{l}493.75 \pm 3.81 \\
\text { b b }\end{array}$ & $\begin{array}{l}538.81 \pm 4.33 \\
\text { a a }\end{array}$ & $\begin{array}{l}503.35 \pm 1.09 \\
\text { b a }\end{array}$ & $\begin{array}{l}442.15 \pm 5.54 \\
\mathrm{~d} \mathrm{c}\end{array}$ \\
\hline & $\begin{array}{l}\text { Low } \\
\text { density }\end{array}$ & $\begin{array}{l}374.15 \pm 4.88 \\
\mathrm{~d} a\end{array}$ & $\begin{array}{l}446.81 \pm 13.66 \\
\text { с a }\end{array}$ & $\begin{array}{l}537.48 \pm 3.21 \\
\text { a a }\end{array}$ & $\begin{array}{l}479.88 \pm 1.29 \\
\text { b b }\end{array}$ & $\begin{array}{l}451.88 \pm 6.71 \\
\mathrm{cb}\end{array}$ & $\begin{array}{l}528.95 \pm 1.50 \\
\text { a a }\end{array}$ \\
\hline & $\begin{array}{l}\text { High } \\
\text { density }\end{array}$ & $\begin{array}{l}178.68 \pm 1.62 \\
c b\end{array}$ & $\begin{array}{l}399.88 \pm 1.85 \\
\text { b b }\end{array}$ & $\begin{array}{l}393.21 \pm 0.74 \\
\text { b c }\end{array}$ & $\begin{array}{l}407.88 \pm 8.81 \\
\text { b c }\end{array}$ & $\begin{array}{l}498.95 \pm 7.05 \\
\text { a a }\end{array}$ & $\begin{array}{l}488.28 \pm 8.58 \\
a b\end{array}$ \\
\hline
\end{tabular}

After 10 days of DPC treatment, without aphids and under low population density stress, differences in cotton protein content between different DPC treatments were significant $(P<0.05)$, but the content of different DPC treatments did not change significantly under high population density stress. Under low population density feeding stress, the protein content of the $0 \mathrm{~g} / \mathrm{L} \mathrm{DPC}$ treatment was only $18.28 \mathrm{mg} / \mathrm{g}$, significantly lower than that of cotton treated with DPC. The protein content of the $0.5 \mathrm{~g} / \mathrm{L} \mathrm{DPC}$ treatment reached the maximum value $(811.08 \mathrm{mg} / \mathrm{g})$, significantly higher than that of cotton without aphid feeding but treated with DPC ( $P>0.05$; Table 1$)$

After 15 days of DPC treatment, the protein content of cotton in $0,0.5 \mathrm{~g} / \mathrm{L}$ and $1 \mathrm{~g} / \mathrm{L} \mathrm{DPC}$ treatments showed no significant differences, while the protein content in other treatments was significantly higher than that in controls. The protein content in the low aphid density and $\geq 0.1 \mathrm{~g} / \mathrm{L} \mathrm{DPC}$ treatments was significantly higher than that of controls, while the protein content in the $0.05 \mathrm{~g} / \mathrm{L} \mathrm{DPC}$ treatment showed no significant differences ( $P>0.05$ ). The protein content of cotton without aphid feeding was only $327.88 \mathrm{mg} / \mathrm{g}$. The protein content of cotton with low aphid density and 0.1 $\mathrm{g} / \mathrm{L} \mathrm{DPC}$ treatment reached the maximum value, significantly higher $(32.3 \%)$ than that of controls. At the same concentration of DPC, the effect of feeding stress on cotton protein content was not significant at $0.5 \mathrm{~g} / \mathrm{L} \mathrm{DPC}$, while the effect of other DPC concentrations on protein content was significant $(P<0.05 ;$ Table 1$)$

After 20 days of DPC treatment, the protein content of cotton was significantly affected by different population densities at the same concentration of DPC. The protein content of cotton treated without aphids first increased then decreased with increasing DPC concentration, and the protein content without DPC treatment was the lowest $(149.75 \mathrm{mg} / \mathrm{g})$, while the protein content of $0.25 \mathrm{~g} / \mathrm{L} \mathrm{DPC}$ treatment was the highest, 2.60 -fold higher than that of controls. Under low aphid density feeding stress, there were significant differences among different concentrations of DPC, and the protein content at $0.1 \mathrm{~g} / \mathrm{L}$ DPC was significantly higher than that without DPC treatment $(537.48 \mathrm{mg} / \mathrm{g})$. Under high insect density feeding stress, the protein content of cotton increased gradually with increasing DPC concentration. There was no significant difference in protein content between $0.05,0.1$, and 0.25 $\mathrm{g} / \mathrm{L}$ treatments, but it was significantly higher than that of cotton without DPC treatment (Table 1).

After 5 days of DPC treatment, there was no significant difference in SOD activity among different treatments. The SOD activity without aphids and $0.1 \mathrm{~g} / \mathrm{L}$ DPC treatment was the highest, significantly higher $(6.79 \%)$ than that of controls $(P<0.05)$. Under high population density stress, the SOD activity of cotton treated with $0.1 \mathrm{~g} / \mathrm{L} \mathrm{DPC}$ was the lowest, significantly lower $(5.76 \%)$ than that of controls $(P<0.05)$. At the same concentration of 
DPC, there was a significant difference in SOD activity between treatment without aphids and a high population density feeding stress, and there was no significant difference in SOD activity between $0.05 \mathrm{~g} / \mathrm{L}$ and $0.5 \mathrm{~g} / \mathrm{L}$ DPC $(P>0.05 ;$ Table 2$)$.

Table 2

Effects of DPC treatment on SOD activity in cotton leaves under aphid feeding stress. Unit, $\mathrm{U} \cdot \mathrm{g}^{-1} \mathrm{FW}$. Black letters for the same time and the same population density indicate significant differences between the different DPC treatments. The red letters in the same column indicate the significant differences between the treatments with different aphid population densities at the same time and the same DPC concentration. There were no significant differences for treatments with the same letter $(p>0.05)$, and there were significant differences between treatments with different letters $(p$ $<0.05)$. Low density, $100-300$ aphids; High density, $>500$ aphids.

\begin{tabular}{|c|c|c|c|c|c|c|c|}
\hline \multirow{2}{*}{$\begin{array}{l}\text { DPC treatment (days after } \\
\text { spraying) }\end{array}$} & \multirow{2}{*}{$\begin{array}{l}\text { Aphid } \\
\text { density }\end{array}$} & \multicolumn{6}{|c|}{ DPC concentration $(\mathrm{g} / \mathrm{L})$} \\
\hline & & 0 & 0.05 & 0.1 & 0.25 & 0.5 & 1 \\
\hline \multirow[t]{3}{*}{$5 d$} & 0 & $\begin{array}{l}12.66 \pm 0.04 b \\
b\end{array}$ & $\begin{array}{l}12.86 \pm 0.08 b \\
a b\end{array}$ & $\begin{array}{l}13.52 \pm 0.10 \\
\text { a a }\end{array}$ & $\begin{array}{l}12.86 \pm 0.09 b \\
a\end{array}$ & $\begin{array}{l}12.71 \pm 0.10 b \\
b\end{array}$ & $\begin{array}{l}12.92 \pm 0.06 b \\
a\end{array}$ \\
\hline & $\begin{array}{l}\text { Low } \\
\text { density }\end{array}$ & $\begin{array}{l}12.96 \pm 0.05 \\
\text { bc a }\end{array}$ & $\begin{array}{l}13.08 \pm 0.09 b \\
a\end{array}$ & $\begin{array}{l}13.35 \pm 0.08 \\
\text { a a }\end{array}$ & $\begin{array}{l}12.52 \pm 0.08 d \\
b\end{array}$ & $\begin{array}{l}13.05 \pm 0.07 b c \\
a\end{array}$ & $\begin{array}{l}12.84 \pm 0.05 \mathrm{c} \\
\mathrm{a}\end{array}$ \\
\hline & $\begin{array}{l}\text { High } \\
\text { density }\end{array}$ & $\begin{array}{l}13.01 \pm 0.12 a \\
a\end{array}$ & $\begin{array}{l}12.76 \pm 0.07 \\
\text { ab b }\end{array}$ & $\begin{array}{l}12.26 \pm 0.53 \\
\text { b b }\end{array}$ & $\begin{array}{l}12.51 \pm 0.12 \\
\text { ab b }\end{array}$ & $\begin{array}{l}12.76 \pm 0.08 a b \\
a b\end{array}$ & $\begin{array}{l}12.43 \pm 0.07 b \\
b\end{array}$ \\
\hline \multirow[t]{3}{*}{$10 \mathrm{~d}$} & 0 & $\begin{array}{l}12.35 \pm 0.06 b \\
b\end{array}$ & $\begin{array}{l}12.46 \pm 0.09 \mathrm{~b} \\
\mathrm{ab}\end{array}$ & $\begin{array}{l}13.23 \pm 0.11 \\
\text { a a }\end{array}$ & $\begin{array}{l}12.48 \pm 0.10 b \\
a\end{array}$ & $\begin{array}{l}12.30 \pm 0.12 b \\
b\end{array}$ & $\begin{array}{l}12.54 \pm 0.07 b \\
a\end{array}$ \\
\hline & $\begin{array}{l}\text { Low } \\
\text { density }\end{array}$ & $\begin{array}{l}12.58 \pm 0.05 \\
\text { bc a }\end{array}$ & $\begin{array}{l}12.71 \pm 0.11 b \\
a\end{array}$ & $\begin{array}{l}13.02 \pm 0.08 \\
\text { a a }\end{array}$ & $\begin{array}{l}12.09 \pm 0.06 \mathrm{~d} \\
\mathrm{~b}\end{array}$ & $\begin{array}{l}12.69 \pm 0.08 b \\
a\end{array}$ & $\begin{array}{l}12.45 \pm 0.05 c \\
a\end{array}$ \\
\hline & $\begin{array}{l}\text { High } \\
\text { density }\end{array}$ & $\begin{array}{l}12.64 \pm 0.08 \mathrm{a} \\
\mathrm{a}\end{array}$ & $\begin{array}{l}12.37 \pm 0.08 \\
\mathrm{ab} \mathrm{b}\end{array}$ & $\begin{array}{l}10.83 \pm 0.60 \\
c b\end{array}$ & $\begin{array}{l}12.09 \pm 0.14 \\
\mathrm{ab} \mathrm{b}\end{array}$ & $\begin{array}{l}12.36 \pm 0.09 a b \\
b\end{array}$ & $\begin{array}{l}12.00 \pm 0.07 b \\
b\end{array}$ \\
\hline \multirow[t]{3}{*}{$15 d$} & 0 & $\begin{array}{l}11.28 \pm 0.06 \mathrm{a} \\
\mathrm{a}\end{array}$ & $\begin{array}{l}11.12 \pm 0.22 \mathrm{a} \\
\mathrm{b}\end{array}$ & $\begin{array}{l}11.01 \pm 0.14 \\
\text { a a }\end{array}$ & $\begin{array}{l}11.26 \pm 0.08 \mathrm{a} \\
\mathrm{a}\end{array}$ & $\begin{array}{l}10.93 \pm 0.12 \mathrm{a} \\
\mathrm{ab}\end{array}$ & $\begin{array}{l}11.10 \pm 0.06 a \\
a\end{array}$ \\
\hline & $\begin{array}{l}\text { Low } \\
\text { density }\end{array}$ & $\begin{array}{l}11.12 \pm 0.16 b \\
a\end{array}$ & $\begin{array}{l}11.79 \pm 0.09 a \\
a\end{array}$ & $\begin{array}{l}11.14 \pm 0.05 \\
\text { b a }\end{array}$ & $\begin{array}{l}10.66 \pm 0.06 \mathrm{c} \\
\mathrm{b}\end{array}$ & $\begin{array}{l}10.44 \pm 0.14 c \\
b\end{array}$ & $\begin{array}{l}10.82 \pm 0.21 \\
\text { bc a }\end{array}$ \\
\hline & $\begin{array}{l}\text { High } \\
\text { density }\end{array}$ & $\begin{array}{l}11.16 \pm 0.02 b \\
a\end{array}$ & $\begin{array}{l}10.96 \pm 0.19 a \\
b\end{array}$ & $\begin{array}{l}10.98 \pm 0.04 \\
\text { b a }\end{array}$ & $\begin{array}{l}11.10 \pm 0.08 \mathrm{c} \\
\mathrm{a}\end{array}$ & $\begin{array}{l}11.04 \pm 0.18 \mathrm{c} \\
\mathrm{a}\end{array}$ & $\begin{array}{l}11.09 \pm 0.10 \\
\text { bc a }\end{array}$ \\
\hline \multirow[t]{3}{*}{$20 \mathrm{~d}$} & 0 & $\begin{array}{l}12.95 \pm 0.13 b \\
a\end{array}$ & $\begin{array}{l}13.56 \pm 0.12 a \\
a\end{array}$ & $\begin{array}{l}13.07 \pm 0.21 \\
\text { b a }\end{array}$ & $\begin{array}{l}11.78 \pm 0.17 d \\
b\end{array}$ & $\begin{array}{l}11.25 \pm 0.11 \mathrm{e} \\
\mathrm{b}\end{array}$ & $\begin{array}{l}12.32 \pm 0.15 \mathrm{c} \\
\mathrm{b}\end{array}$ \\
\hline & $\begin{array}{l}\text { Low } \\
\text { density }\end{array}$ & $\begin{array}{l}12.23 \pm 0.19 d \\
b\end{array}$ & $\begin{array}{l}12.71 \pm 0.07 \\
\text { bc c }\end{array}$ & $\begin{array}{l}13.28 \pm 0.07 \\
\text { a a }\end{array}$ & $\begin{array}{l}12.93 \pm 0.14 \\
\text { ab a }\end{array}$ & $\begin{array}{l}12.44 \pm 0.21 \mathrm{~cd} \\
\mathrm{a}\end{array}$ & $\begin{array}{l}12.92 \pm 0.05 \\
\text { ab a }\end{array}$ \\
\hline & $\begin{array}{l}\text { High } \\
\text { density }\end{array}$ & $\begin{array}{l}12.77 \pm 0.14 b \\
a\end{array}$ & $\begin{array}{l}13.14 \pm 0.08 \mathrm{a} \\
\mathrm{b}\end{array}$ & $\begin{array}{l}13.16 \pm 0.04 \\
\text { a a }\end{array}$ & $\begin{array}{l}12.81 \pm 0.12 b \\
a\end{array}$ & $\begin{array}{l}12.85 \pm 0.06 a b \\
a\end{array}$ & $\begin{array}{l}12.79 \pm 0.13 b \\
a\end{array}$ \\
\hline
\end{tabular}

After 10 days of DPC treatment, the SOD activity without aphids and $0.05 \mathrm{~g} / \mathrm{L}$ or $0.1 \mathrm{~g} / \mathrm{L} \mathrm{DPC}$ treatments was significantly different from that of the same period, and the activity of $0.1 \mathrm{~g} / \mathrm{L} \mathrm{DPC}$ treatment was the highest $\left(13.23 \mathrm{U} \cdot \mathrm{g}^{-1} \mathrm{FW}\right)$. Under $0.1 \mathrm{~g} / \mathrm{L}$ DPC treatment, the SOD activity of cotton treated with low and high population densities was significantly different from that of controls. The SOD activity of cotton treated with low population density was significantly higher (3.50\%) than that of controls, while the SOD activity of cotton treated with high insect density was the lowest, significantly lower (14.32\%) than that of controls. At the same DPC concentration, SOD activity was highest under low population density feeding stress, and the SOD activity of cotton treated with $0.25 \mathrm{~g} / \mathrm{L} \mathrm{DPC}$ was significantly lower than that of cotton not exposed to aphids $(P<0.05$; Table 2$)$.

After 15 days of DPC treatment, the SOD activity of cotton was generally lower than that of other treatment durations, and under low aphid density feeding stress, the SOD activity of cotton treated with $0.05 \mathrm{~g} / \mathrm{L} \mathrm{DPC}$ was the highest $\left(11.79 \mathrm{U} \cdot \mathrm{g}^{-1} \mathrm{FW}\right)$, but there was no significant difference compared with controls at the same time (P>0.05). The SOD activity of $0.5 \mathrm{~g} / \mathrm{L}$ DPC-treated cotton was only $10.44 \mathrm{U} \cdot \mathrm{g}^{-1} \mathrm{FW}$, which was not significantly different from that of controls $(P>0.05)$. There was no significant difference in SOD activity of cotton treated without aphids and high population density stress with different DPC concentrations, while the SOD activity of cotton treated with low population density stress first increased then decreased with increasing DPC concentration, and the SOD activity was highest at $0.05 \mathrm{~g} / \mathrm{L} \mathrm{DPC}$, significantly higher than that of cotton without aphid feeding (Table 2).

After 20 days of DPC treatment, the SOD activity of cotton without aphids was significantly different among different concentrations of DPC, and the SOD activity of $0.05 \mathrm{~g} / \mathrm{L} \mathrm{DPC}$ was the highest, significantly higher $(4.71 \%)$ than that of controls $(P<0.05)$, while the SOD activity of $0.5 \mathrm{~g} / \mathrm{L}$ DPC was lowest value, significantly lower (13.13\%) than that of controls $(P<0.05)$. The SOD activity of cotton under low population density feeding stress changed markedly with increasing concentration of DPC, first increasing then decreasing, and reaching a maximum at $0.05 \mathrm{~g} / \mathrm{L}$ DPC, significantly higher than that of cotton without DPC treatment. However, the SOD activity difference at this DPC concentration was the most significant, and the 
SOD activity under low population density feeding stress was significantly lower (6.27\%) than that of cotton without aphid feeding ( $P>0.05)$. The SOD activity of cotton under high population density feeding stress changed gently with increasing DPC concentration, and there was no significant difference between treatments. The SOD activity was significantly higher than that of controls only when the concentration of DPC was $0.05 \mathrm{~g} / \mathrm{L}$ or $0.1 \mathrm{~g} / \mathrm{L}(P<0.05$; Table 2).

After 5 days of DPC treatment, the POD activity of cotton without aphids and with low population density stress was significantly different with changing DPC concentration $(P<0.05)$. At low population density stress and $0.1 \mathrm{~g} / \mathrm{L}$ DPC treatment, POD activity was the lowest $(6400$ $\left.\mathrm{OD}_{470} \cdot \mathrm{min}^{-1} \cdot \mathrm{g}^{-1} \mathrm{FW}\right)$. Meanwhile, under high density feeding stress, the POD activity of cotton was not significantly affected by different concentrations of DPC, and the POD activity reached the highest value at $0.25 \mathrm{~g} / \mathrm{L} \mathrm{DPC}$, significantly higher (62.54\%) than for untreated controls. Under $1 \mathrm{~g} / \mathrm{L}$ DPC treatment, the POD activity of cotton did not change significantly under different population densities ( $P>0.05)$. With DPC concentrations $<1 \mathrm{~g} / \mathrm{L}$, the change in enzyme activity in different population densities was significant $(P<0.05)$, and the POD activity under high population density was the highest under the same concentration of DPC. (Table 3).

Table 3

Effects of DPC treatment on POD activity in cotton leaves under aphid feeding stress. Unit, $\mathrm{OD}_{470} \cdot \mathrm{min}^{-1} \cdot \mathrm{g}^{-1} \mathrm{FW}$. Black letters for the same time and the same population density indicate significant differences between the different DPC treatments. The red letters in the same column indicate significant differences between the treatments for the different aphid population densities at the same time and the same DPC concentration. There were no significant differences for treatments with the same letter $(p>0.05)$, and there were significant differences between treatments with different letters ( $p$ $<0.05)$. Low density, 100-300 aphids; High density, $>500$ aphids.

\begin{tabular}{|c|c|c|c|c|c|c|c|}
\hline \multirow{2}{*}{$\begin{array}{l}\text { DPC } \\
\text { treatment } \\
\text { (days } \\
\text { after } \\
\text { spraying) }\end{array}$} & \multirow{2}{*}{$\begin{array}{l}\text { Aphid } \\
\text { density }\end{array}$} & \multicolumn{6}{|c|}{ DPC concentration $(\mathrm{g} / \mathrm{L})$} \\
\hline & & 0 & 0.05 & 0.1 & 0.25 & 0.5 & 1 \\
\hline \multirow[t]{3}{*}{$5 d$} & 0 & $\begin{array}{l}9863.33 \pm 287.52 \\
\text { e b }\end{array}$ & $\begin{array}{l}11143.33 \pm 479.55 \\
d \text { b }\end{array}$ & $\begin{array}{l}8736.67 \pm 278.51 \\
\mathrm{fb}\end{array}$ & $\begin{array}{l}15438.33 \pm 251.60 \\
\text { a b }\end{array}$ & $\begin{array}{l}12110.00 \pm 37.86 \\
\text { C C }\end{array}$ & $\begin{array}{l}13920.00 \pm 64.49 \\
\mathrm{~b} \mathrm{a}\end{array}$ \\
\hline & $\begin{array}{l}\text { Low } \\
\text { density }\end{array}$ & $\begin{array}{l}7591.67 \pm 15.90 \mathrm{~d} \\
\mathrm{C}\end{array}$ & $\begin{array}{l}10545.00 \pm 37.38 \\
c b\end{array}$ & $\begin{array}{l}6400.00 \pm 244.34 \\
\text { e c }\end{array}$ & $\begin{array}{l}11758.33 \pm 290.12 \\
\text { b c }\end{array}$ & $\begin{array}{l}13653.33 \pm 129.82 \\
a b\end{array}$ & $\begin{array}{l}11563.33 \pm 79.07 \\
\text { b b }\end{array}$ \\
\hline & $\begin{array}{l}\text { High } \\
\text { density }\end{array}$ & $\begin{array}{l}15900.00 \pm 162.10 \\
\text { b a }\end{array}$ & $\begin{array}{l}14960.00 \pm 129.23 \\
\text { ab a }\end{array}$ & $\begin{array}{l}15121.67 \pm 48.07 \\
\text { ab a }\end{array}$ & $\begin{array}{l}16031.67 \pm 59.25 \\
\text { a a }\end{array}$ & $\begin{array}{l}14338.33 \pm 137.15 \\
\text { ab a }\end{array}$ & $\begin{array}{l}13911.67 \pm 192.04 \\
\text { b a }\end{array}$ \\
\hline \multirow[t]{3}{*}{$10 \mathrm{~d}$} & 0 & $\begin{array}{l}7230.00 \pm 91.70 \mathrm{f} \\
\mathrm{b}\end{array}$ & $\begin{array}{l}10283.33 \pm 116.92 \\
\mathrm{c} \mathrm{b}\end{array}$ & $\begin{array}{l}8158.33 \pm 62.27 \\
\text { e c }\end{array}$ & $8671.67 \pm 4.41 \mathrm{~d} \mathrm{c}$ & $\begin{array}{l}15630.00 \pm 18.93 \\
\text { a a }\end{array}$ & $\begin{array}{l}14615.00 \pm 49.24 \\
\text { b b }\end{array}$ \\
\hline & $\begin{array}{l}\text { Low } \\
\text { density }\end{array}$ & $\begin{array}{l}6136.67 \pm 19.65 f \\
C\end{array}$ & $\begin{array}{l}10571.67 \pm 8.82 \mathrm{~d} \\
\mathrm{~b}\end{array}$ & $\begin{array}{l}14626.67 \pm 28.33 \\
\text { a a }\end{array}$ & $\begin{array}{l}12270.00 \pm 5.77 b \\
b\end{array}$ & $\begin{array}{l}11411.67 \pm 103.13 \\
\mathrm{c} \mathrm{b}\end{array}$ & $\begin{array}{l}8021.67 \pm 34.68 \mathrm{e} \\
\mathrm{c}\end{array}$ \\
\hline & $\begin{array}{l}\text { High } \\
\text { density }\end{array}$ & $\begin{array}{l}14471.67 \pm 168.98 \\
\text { b a }\end{array}$ & $\begin{array}{l}13481.67 \pm 108.06 \\
\text { c a }\end{array}$ & $\begin{array}{l}10368.33 \pm 54.19 \\
\text { e b }\end{array}$ & $\begin{array}{l}12336.67 \pm 9.28 \mathrm{~d} \\
\mathrm{a}\end{array}$ & $\begin{array}{l}5718.33 \pm 134.79 \\
\text { f c }\end{array}$ & $\begin{array}{l}15561.67 \pm 12.02 \\
\text { a a }\end{array}$ \\
\hline \multirow[t]{3}{*}{$15 d$} & 0 & $2415.00 \pm 2.89$ e c & $\begin{array}{l}9103.33 \pm 104.50 \\
\text { b a }\end{array}$ & $\begin{array}{l}6495.00 \pm 45.37 \\
\text { c a }\end{array}$ & $1813.33 \pm 8.82 \mathrm{f} \mathrm{c}$ & $\begin{array}{l}13385.00 \pm 100.04 \\
\text { a a }\end{array}$ & $\begin{array}{l}4085.00 \pm 58.38 \mathrm{~d} \\
\mathrm{C}\end{array}$ \\
\hline & $\begin{array}{l}\text { Low } \\
\text { density }\end{array}$ & $\begin{array}{l}3816.67 \pm 156.96 \\
\text { c a }\end{array}$ & $\begin{array}{l}1330.00 \pm 68.25 \mathrm{~d} \\
\mathrm{C}\end{array}$ & $\begin{array}{l}3890.00 \pm 86.07 \\
\text { C C }\end{array}$ & $\begin{array}{l}3826.67 \pm 114.18 \\
\mathrm{cb}\end{array}$ & $\begin{array}{l}4560.00 \pm 24.66 \mathrm{~b} \\
\mathrm{c}\end{array}$ & $\begin{array}{l}5428.33 \pm 58.40 \text { a } \\
a\end{array}$ \\
\hline & $\begin{array}{l}\text { High } \\
\text { density }\end{array}$ & $\begin{array}{l}3420.00 \pm 57.74 \mathrm{e} \\
\mathrm{b}\end{array}$ & $\begin{array}{l}4421.67 \pm 90.48 d \\
b\end{array}$ & $\begin{array}{l}5038.33 \pm 17.64 \\
\mathrm{cb}\end{array}$ & $\begin{array}{l}8145.00 \pm 47.52 \mathrm{a} \\
\mathrm{a}\end{array}$ & $\begin{array}{l}6003.33 \pm 100.84 \\
\text { b b }\end{array}$ & $\begin{array}{l}5061.67 \pm 68.46 \mathrm{c} \\
\mathrm{b}\end{array}$ \\
\hline \multirow[t]{3}{*}{$20 d$} & 0 & $\begin{array}{l}2651.67 \pm 41.87 \mathrm{f} \\
\mathrm{C}\end{array}$ & $\begin{array}{l}6851.67 \pm 95.50 \mathrm{e} \\
\mathrm{b}\end{array}$ & $\begin{array}{l}7456.67 \pm 106.31 \\
d b\end{array}$ & $\begin{array}{l}10038.33 \pm 159.17 \\
\text { c b }\end{array}$ & $\begin{array}{l}15598.33 \pm 21.67 \\
\text { b b }\end{array}$ & $\begin{array}{l}16243.33 \pm 128.85 \\
\text { a a }\end{array}$ \\
\hline & $\begin{array}{l}\text { Low } \\
\text { density }\end{array}$ & $\begin{array}{l}3550.00 \pm 64.49 d \\
b\end{array}$ & $\begin{array}{l}12491.67 \pm 34.80 \\
\text { b a }\end{array}$ & $\begin{array}{l}10060.00 \pm 38.84 \\
\text { c a }\end{array}$ & $\begin{array}{l}12711.67 \pm 69.36 \\
\text { b a }\end{array}$ & $\begin{array}{l}17148.33 \pm 194.60 \\
\text { a a }\end{array}$ & $\begin{array}{l}12690.00 \pm 77.51 \\
\text { b b }\end{array}$ \\
\hline & $\begin{array}{l}\text { High } \\
\text { density }\end{array}$ & $\begin{array}{l}6011.67 \pm 60.09 \mathrm{c} \\
\mathrm{a}\end{array}$ & $\begin{array}{l}5676.67 \pm 20.88 d \\
C\end{array}$ & $\begin{array}{l}2673.33 \pm 114.65 \\
\text { e c }\end{array}$ & $\begin{array}{l}5886.67 \pm 136.94 \\
\text { cd c }\end{array}$ & $\begin{array}{l}9436.67 \pm 92.62 b \\
c\end{array}$ & $\begin{array}{l}10005.00 \pm 67.88 \\
\text { a c }\end{array}$ \\
\hline
\end{tabular}

After 15 days of DPC treatment, the POD activity without aphids was significantly different with different concentrations of DPC, and the POD activity reached the maximum value at $0.5 \mathrm{~g} / \mathrm{L} \mathrm{DPC}, 4.54$-fold higher than that of controls at the same period. Under low density feeding stress, POD activity of cotton increased with increasing DPC concentration, and POD activity was lowest under $0.05 \mathrm{~g} / \mathrm{L}$ DPC treatment, significantly lower (65.14\%) than that of controls. Under with high insect population density feeding stress, the POD activity of cotton first increased then decreased with increasing DPC concentration. POD activity was highest under treatment with $0.25 \mathrm{~g} / \mathrm{L} \mathrm{DPC}, 1.38$-fold higher than without DPC treatment Under the same DPC concentration, the effects of different population densities on POD activity of cotton were significant $(P<0.05$; Table 3$)$.

After 20 days of DPC treatment, the POD activity of cotton under low population density feeding stress was significantly different with different DPC concentrations, and the POD activity reached the maximum value under $0.5 \mathrm{~g} / \mathrm{L}$ DPC treatment, 3.83 -fold higher than that without DPC treatment. At 
DPC concentrations $<0.25 \mathrm{~g} / \mathrm{L}$, the POD activity of cotton decreased with increasing DPC concentration under high insect density feeding stress, and the POD activity was lowest at $0.1 \mathrm{~g} / \mathrm{L} \mathrm{DPC}\left(2673.33 \mathrm{OD}_{470} \cdot \mathrm{min}^{-1} \cdot \mathrm{g}^{-1} \mathrm{FW}\right)$, significantly lower (55.53\%) than that of cotton without DPC treatment. The POD activity of cotton increased with increasing DPC concentration when the concentration of DPC was $\geq 0.25 \mathrm{~g} / \mathrm{L}$. The POD activity of cotton with low population density stress was significantly higher than that of cotton with high population density stress $(P<0.05 ;$ Table 3$)$.

After 5 days of DPC treatment, when the concentration of DPC was $\leq 0.25 \mathrm{~g} / \mathrm{L}$, the CAT activity of cotton without aphids gradually increased with increasing DPC concentration, and the CAT activity reached the maximum value at $0.25 \mathrm{~g} / \mathrm{L} \mathrm{DPC}$, significantly higher (71.96\%) than that of untreated controls. When the concentration of DPC was $>0.25 \mathrm{~g} / \mathrm{L}$, the CAT activity of cotton without aphid treatment decreased significantly with increasing DPC concentration $(P<0.05)$. The CAT activity under low population density stress first decreased then increased with increasing DPC concentration, and the CAT activity reached the minimum value at the concentration of $0.25 \mathrm{~g} / \mathrm{L}$, significantly lower (50\%) than that of cotton without DPC treatment. At concentrations of DPC $<0.25 \mathrm{~g} / \mathrm{L}$, there was a significant difference in CAT activity with population density without the application of DPC, and the CAT activity of cotton at a high population density was significantly lower (35.93\%) than that at a high population density $(P<0.05$; Table 4$)$.

Table 4

Effects of DPC treatment on CAT activity in cotton leaves under aphid feeding stress. Unit, $\mathrm{OD}_{240} \cdot \mathrm{min}^{-1} \cdot \mathrm{g}^{-1} \mathrm{FW}$. Black letters for the same time and the same population density indicate significant differences between the different DPC treatments. Red letters in the same column indicate the significant differences between the treatments for different aphid population densities at the same time and the DPC same concentration. There were no significant differences for treatments with the same letter $(p>0.05)$, and there were significant differences between treatments with different letters $(p$ $<0.05)$. Low density, 100-300 aphids; High density, $>500$ aphids.

\begin{tabular}{|c|c|c|c|c|c|c|c|}
\hline \multirow{2}{*}{$\begin{array}{l}\text { DPC treatment } \\
\text { (days after } \\
\text { spraying) }\end{array}$} & \multirow{2}{*}{$\begin{array}{l}\text { Aphid } \\
\text { density }\end{array}$} & \multicolumn{6}{|c|}{ DPC concentration $(\mathrm{g} / \mathrm{L})$} \\
\hline & & 0 & 0.05 & 0.1 & 0.25 & 0.5 & 1 \\
\hline \multirow[t]{3}{*}{$5 d$} & 0 & $\begin{array}{l}796.67 \pm 18.56 d \\
b\end{array}$ & $\begin{array}{l}946.67 \pm 20.28 \\
\text { cd b }\end{array}$ & $\begin{array}{l}1040.00 \pm 26.46 \\
\text { bc a }\end{array}$ & $\begin{array}{l}1370.00 \pm 127.02 \\
\text { a a }\end{array}$ & $\begin{array}{l}1180.00 \pm 55.08 \\
\text { b a }\end{array}$ & $\begin{array}{l}953.33 \pm 38.44 \\
\text { cd a }\end{array}$ \\
\hline & $\begin{array}{l}\text { Low } \\
\text { density }\end{array}$ & $\begin{array}{l}1260.00 \pm 45.09 \\
\mathrm{ab} \mathrm{a}\end{array}$ & $\begin{array}{l}1326.67 \pm 49.78 \\
\text { a a }\end{array}$ & $\begin{array}{l}1103.33 \pm 50.44 \\
\text { bc a }\end{array}$ & $\begin{array}{l}630.00 \pm 32.15 d \\
b\end{array}$ & $\begin{array}{l}956.67 \pm 20.28 \\
c b\end{array}$ & $\begin{array}{l}1153.33 \pm 90.62 \\
\text { b a }\end{array}$ \\
\hline & $\begin{array}{l}\text { High } \\
\text { density }\end{array}$ & $\begin{array}{l}510.00 \pm 56.86 \mathrm{~d} \\
\mathrm{C}\end{array}$ & $\begin{array}{l}1310.00 \pm 75.06 \\
\text { a a }\end{array}$ & $\begin{array}{l}983.33 \pm 26.67 \\
\text { c a }\end{array}$ & $\begin{array}{l}1093.33 \pm 94.04 \\
\text { bc a }\end{array}$ & $\begin{array}{l}1200.00 \pm 75.72 \\
\text { ab a }\end{array}$ & $\begin{array}{l}1030.00 \pm 20.82 \\
\text { bc a }\end{array}$ \\
\hline \multirow[t]{3}{*}{$10 \mathrm{~d}$} & 0 & $\begin{array}{l}1275.00 \pm 31.22 \\
\text { b b }\end{array}$ & $\begin{array}{l}1338.33 \pm 39.83 \\
\text { b b }\end{array}$ & $\begin{array}{l}1680.00 \pm 55.08 \\
\text { a a }\end{array}$ & $\begin{array}{l}1751.67 \pm 45.31 \\
\text { a a }\end{array}$ & $\begin{array}{l}1761.67 \pm 31.93 \\
\text { a a }\end{array}$ & $\begin{array}{l}1340.00 \pm 52.92 \\
\text { b b }\end{array}$ \\
\hline & $\begin{array}{l}\text { Low } \\
\text { density }\end{array}$ & $\begin{array}{l}1875.00 \pm 36.17 \\
\text { a a }\end{array}$ & $\begin{array}{l}1858.33 \pm 35.63 \\
\text { a a }\end{array}$ & $\begin{array}{l}1588.33 \pm 24.55 \\
\mathrm{~b} \mathrm{a}\end{array}$ & $\begin{array}{l}956.67 \pm 26.67 d \\
C\end{array}$ & $\begin{array}{l}1443.33 \pm 58.40 \\
\mathrm{c} \mathrm{b}\end{array}$ & $\begin{array}{l}1541.67 \pm 51.99 \\
\text { bc ab }\end{array}$ \\
\hline & $\begin{array}{l}\text { High } \\
\text { density }\end{array}$ & $\begin{array}{l}870.00 \pm 34.64 \mathrm{c} \\
\mathrm{c}\end{array}$ & $\begin{array}{l}1713.33 \pm 82.93 \\
\text { a a }\end{array}$ & $\begin{array}{l}1408.33 \pm 55.25 \\
\text { b b }\end{array}$ & $\begin{array}{l}1506.67 \pm 80.07 \\
\text { ab b }\end{array}$ & $\begin{array}{l}1553.33 \pm 41.77 \\
a b b\end{array}$ & $\begin{array}{l}1640.00 \pm 70.95 \\
\text { a a }\end{array}$ \\
\hline \multirow[t]{3}{*}{$15 d$} & 0 & $\begin{array}{l}2116.67 \pm 43.33 \\
\text { bc b }\end{array}$ & $\begin{array}{l}2030.00 \pm 15.28 \\
\mathrm{~cd} \mathrm{~b}\end{array}$ & $\begin{array}{l}2236.67 \pm 18.56 \\
\text { ab a }\end{array}$ & $\begin{array}{l}2346.67 \pm 26.67 \\
\text { a a }\end{array}$ & $\begin{array}{l}1973.33 \pm 62.27 \\
d b\end{array}$ & $\begin{array}{l}2230.00 \pm 40.41 \\
\mathrm{ab} \mathrm{a}\end{array}$ \\
\hline & $\begin{array}{l}\text { Low } \\
\text { density }\end{array}$ & $\begin{array}{l}2996.67 \pm 29.06 \\
\text { a a }\end{array}$ & $\begin{array}{l}2513.33 \pm 23.33 \\
\text { b a }\end{array}$ & $\begin{array}{l}1666.67 \pm 46.67 \\
d b\end{array}$ & $\begin{array}{l}2566.67 \pm 143.80 \\
\text { cd a }\end{array}$ & $\begin{array}{l}2496.67 \pm 27.28 \\
\text { b a }\end{array}$ & $\begin{array}{l}2223.33 \pm 28.48 \\
\text { bc a }\end{array}$ \\
\hline & $\begin{array}{l}\text { High } \\
\text { density }\end{array}$ & $\begin{array}{l}2010.00 \pm 51.32 \\
c b\end{array}$ & $\begin{array}{l}2026.67 \pm 18.56 \\
c b\end{array}$ & $\begin{array}{l}2350.00 \pm 70.24 \\
\mathrm{~b} \mathrm{a}\end{array}$ & $\begin{array}{l}2506.67 \pm 13.33 \\
\text { a a }\end{array}$ & $\begin{array}{l}1593.33 \pm 18.56 \\
\mathrm{~d} \mathrm{c}\end{array}$ & $\begin{array}{l}1600.00 \pm 26.46 \\
d b\end{array}$ \\
\hline \multirow[t]{3}{*}{$20 d$} & 0 & $\begin{array}{l}550.00 \pm 26.46 \mathrm{~d} \\
\mathrm{~b}\end{array}$ & $\begin{array}{l}1360.00 \pm 20.82 \\
c b\end{array}$ & $\begin{array}{l}1330.00 \pm 20.82 \\
c b\end{array}$ & $\begin{array}{l}1833.33 \pm 31.80 \\
\text { a a }\end{array}$ & $\begin{array}{l}1326.67 \pm 18.56 \\
c b\end{array}$ & $\begin{array}{l}1696.67 \pm 33.83 \\
\text { b a }\end{array}$ \\
\hline & $\begin{array}{l}\text { Low } \\
\text { density }\end{array}$ & $\begin{array}{l}3113.33 \pm 124.41 \\
\text { а a }\end{array}$ & $\begin{array}{l}1223.33 \pm 21.86 \\
\mathrm{~d} \mathrm{c}\end{array}$ & $\begin{array}{l}1796.67 \pm 39.30 \\
\text { b a }\end{array}$ & $\begin{array}{l}1566.67 \pm 86.86 \\
\text { c b }\end{array}$ & $\begin{array}{l}1823.33 \pm 80.90 \\
\mathrm{~b} \mathrm{a}\end{array}$ & $\begin{array}{l}1546.67 \pm 35.28 \\
\text { с a }\end{array}$ \\
\hline & $\begin{array}{l}\text { High } \\
\text { density }\end{array}$ & $\begin{array}{l}683.33 \pm 31.80 \mathrm{c} \\
\mathrm{b}\end{array}$ & $\begin{array}{l}1630.00 \pm 20.82 \\
\text { a a }\end{array}$ & $\begin{array}{l}1406.67 \pm 18.56 \\
\text { b b }\end{array}$ & $\begin{array}{l}1656.67 \pm 48.07 \\
a \mathrm{ab}\end{array}$ & $\begin{array}{l}1426.67 \pm 24.04 \\
\text { b b }\end{array}$ & $\begin{array}{l}1556.67 \pm 69.84 \\
\text { a a }\end{array}$ \\
\hline
\end{tabular}

After 10 days of DPC treatment, the CAT activity of cotton without aphid treatment increased gradually with increasing concentration of DPC at DPC $\leq 0.5 \mathrm{~g} / \mathrm{L}$, and the CAT activity reached the maximum value at $0.5 \mathrm{~g} / \mathrm{L}$, significantly higher (38.1\%) that that without any treatment. At a DPC concentration of $1 \mathrm{~g} / \mathrm{L}$, the CAT activity of cotton treated without aphids decreased significantly $(P<0.05)$. CAT activity under low insect density stress showed the opposite trend, first decreasing then increasing with increasing DPC concentration, and CAT activity reached a minimum value at $0.25 \mathrm{~g} / \mathrm{L}$ DPC, significantly lower $(49.0 \%)$ than that of cotton not treated with DPC $(P<0.05)$. The CAT activity of cotton under high density feeding stress was significantly different $(P<0.05$; Table 4$)$.

After 15 days of DPC treatment, the CAT activity without aphids and under low population density stress was significantly different with increasing DPC concentration. Under high population density stress, at DPC $\leq 0.25 \mathrm{~g} / \mathrm{L}$ the CAT activity of cotton increased gradually with increasing DPC concentration, and the CAT activity reached the maximum value under $0.25 \mathrm{~g} / \mathrm{L} \mathrm{DPC}$, significantly higher than that of controls. With increasing DPC 
concentration, the CAT activity decreased gradually, and it reached the minimum value at $0.5 \mathrm{~g} / \mathrm{L} \mathrm{DPC}$, significantly lower (20.7 \%) than that of cotton without DPC treatment. Under the same concentration of DPC, there was no significant change in CAT activity among different aphid density treatments ( $P>0.05$; Table 4).

After 20 days of DPC treatment, the CAT activity of cotton under different population densities was significantly different with different concentrations of DPC. Without aphids, there was no significant difference in CAT activity between $0.05,0.1$, and $0.5 \mathrm{~g} / \mathrm{L}$ DPC treatments, and the CAT activity without DPC treatment was the lowest $\left(550 \mathrm{OD}_{470} \cdot \mathrm{min}^{-1} \cdot \mathrm{g}^{-1} \mathrm{FW}\right)$. Under high population density stress, the CAT activity of cotton not treated with DPC was $24.18 \%$ higher than that of cotton without any treatment, but the difference was not significant ( $P>0.05)$. The CAT activity of cotton under low population density stress was the highest, 4.66 -fold higher than that of cotton without any treatment. When treated with $1 \mathrm{~g} / \mathrm{L}$ DPC, the difference in CAT activity with population density was not significant ( $P>0.05$; Table 4 ).

\section{Discussion}

When plants are subjected to stress, the balance between the production and elimination of reactive oxygen species (ROS) is disrupted, and the elimination of ROS mainly relies on antioxidant enzyme systems such as SOD, POD, and CAT, as well as other non-enzymatic systems (Xu et al., 2011). Plant growth regulators can optimize cellular physiological and biochemical metabolism in plants, and enhance resistance by increasing the levels of antioxidant enzymes (Liang et al., 1999; Hu and Li, 2009; Nie et al., 2010). In the present study, spraying DPC at different concentrations enhanced the soluble protein content and POD and CAT activities in plants. When the DPC concentration was $\leq 0.1 \mathrm{~g} / \mathrm{L}$, the SOD activity also showed an increasing trend. However, after 20 days of DPC treatment, the SOD and CAT activities in cotton showed opposite trends compared with those in the early stage of the experiment, which might be due to a gradual decrease in the efficacy of DPC over time.

DPC enhanced cotton resistance through a variety of ways. For example, DPC enhances cotton drought resistance by promoting root growth (Xu and Taylor, 1992; Muhammad et al., 2005). Furthermore, DPC enhances the photosynthetic physiology of cotton leaves by increasing chlorophyll content, photosynthetic rate, and the relative chlorophyll content (SPAD value) (Deng et al., 2013; Cui and Wang, 2017). DPC also improves cell membrane stability by regulating inorganic salts such as $\mathrm{Na}^{+}, \mathrm{K}^{+}$, and $\mathrm{Cl}^{-}$(Kamran et al.,2018; Wang et al., 2019, 2020), enhancing cell osmotic pressure resistance by increasing proline and protein content in cotton (Zhou et al., 2010; Deng et al., 2013), and enhancing secondary metabolites of cotton by increasing phenolic acids such as lignin, total phenols, and tannins (Cui et al., 2017). The present work showed that DPC enhanced stress resistance by increasing the metabolic levels of antioxidant enzymes such as SOD, POD, and CAT in cotton.

Increased use of DPC can enhance stress resistance in many plants. In the growth process of peanut and sunflower, application of DPC can reduce the MDA content and plant height, increase the activity of protective enzymes, and improve stress resistance (Xuan et al., 2010; Liu et al., 2018). Similarly, spraying DPC on winter barley, rape, and maize can reduce plant height, improve stem physical strength, and enhance plant lodging resistance (White, 1991; Armstrong and Nicol, 1991; Kamran et al., 2018). DPC enhances the drought resistance of Eucalyptus tree species by promoting root growth (Juscelina et al., 2020). In cotton, DPC can inhibit the occurrence of some pests and diseases, such as cotton bollworm, spider mites, and cotton verticillium wilt (Ma et al., 1994; Shu et al., 1996; Dong et al.,2000). Our results show that DPC can increase the tolerance of cotton to aphids. However, in the face of different external pressures, the mechanism by which DPC improves plant resistance and adaptation requires further investigation.

DPC not only regulates the growth of cotton; it also affects insect pests feeding on cotton. For example, when DPC was applied in the field, the survival number of 100 larvae of Helicoverpa armigera decreased by $28.7 \%$ compared with blank controls, the damage rates of top and bud bolls decreased by $6.6 \%$ and $11.1 \%$ respectively (Ma et al., 1994), and the reproduction rate of spider mites decreased by $45.7 \%$ and $57.33 \%$ (Shu et al., 1996). In order to prevent DPC from affecting themselves, insects activate metabolic detoxification enzymes such as GST and carboxylesterase to degrade exogenous toxins and maintain normal physiological metabolism (Mutunga et al., 2015). In the present study, field and laboratory experiments showed that DPC could significantly increase GST activity in cotton aphids, but the activities of carboxylesterase and acetylcholinesterase were downregulated, indicating that DPC was also toxic to cotton aphids during application to cotton fields, presumably by altering detoxification enzyme activities in cotton aphids, and the main target of DPC in cotton aphids was GST.

Plant growth regulators affect all aspects of plant growth, and plant-insect interactions are also likely to be affected (Zummo et al., 1984). During the growth period of cotton, the use of DPC also affected the interaction between cotton and cotton bollworm. DPC induces cotton to produce more tannins and terpenoids, both of which are related to insect resistance to cotton (Zummo et al., 1983). DPC also causes the cotton bollworm to resist feeding, and reduces its growth and survival rates, thereby reducing the harmfulness of cotton bollworm to cotton (Zummo et al., 1984). In this study, we have similar found that DPC also affected this relationship in a cotton-cotton aphid system. Regarding damage by different densities of cotton aphids, DPC positively responded to cotton aphid stress by inducing the production of protective enzymes and proteins in cotton, and enhanced the resistance of cotton to aphids.

\section{Conclusion}

In summary, this study showed that DPC stimulated the protective enzyme defense mechanism in cotton in a cotton-cotton aphid system. DPC also had a direct toxic effect on cotton aphids, and targeted GST in the insects, which had a positive effect on alleviating the responses of cotton to cotton 
aphid stress. However, the mechanism by which DPC mediates cotton defenses against cotton aphids requires further investigation to identify the genes/proteins, pathways, and regulatory aspects involved.

\section{Abbreviations}

DPC: Mepiquat chloride

GST: Glutathione S-transferase

POD: Peroxidase

CAT: Catalase

SOD: Superoxide dismutase

MDA: Malondialdehyde

Declarations

\section{Availability of data and materials}

All data generated or analyzed during this study are included in this article.

\section{Acknowledgements}

We thank Pro. Hong Shen for help and suggestions in the study, and thank anonymous reviewers and the editors for their valuable comments and suggestions on the manuscript.

\section{Funding}

This research was supported by the National Natural Science Foundation of China (Grant No. 31660519).

\section{Author information}

Affiliations

Laboratory of Toxicology and Biological Control of Agriculture Pest, College of Agriculture, Shihezi University, Shihezi 832003, China

Quan-Cheng Zhang, Xiao-Xia Deng, Jun-Gang Wang

\section{Contributions}

Quan-Cheng Zhang wrote the article, Xiao-Xia Deng processed the data and charts of the article, and Jun-Gang Wang reviewed the article. All of the authors read and approved the final manuscript.

\section{Ethics declarations}

\section{Ethics approval and consent to participate}

The experiments carried out by the institute are legal, and we abide by national or international norms and legislation in the course of the study.

\section{Competing interests}

We declare that we have no competing interests.

\section{References}

1. Armstrong EL, Nico HIl. Reducing height and lodging in rapeseed with growth regulators. Animal Production Science. 1991;31:245-250. 
2. Bradford MM. A rapid and sensitive method for the quantitation of microgram quantities of protein utilizing the principle of protein-dye binding. Anal Biochem. 1976;72:248-54.

3. Chen YZ, Dong HZ. Mechanisms and regulation of senescence and maturity performance in cotton. Field Crops Res. 2016;189:1-9.

4. Cui JL, Wang JG, Zhong L, Li WJ. Effects of mepiquat chloride (DPC) on energy substances in Aphis gossypii. Journal of Environmental Entomology. 2018;40:446-451.

5. Cui JL, Wang QL, Zhong L, Li WJ, Wang JG. Effect of mepiquat chloride on the content of phenolic acid secondary metabolites in cotton leaves. Xinjiang Agricultural Sciences. 2017;45:99-101.

6. Cui JL, Wang JG. Effects of mepiquat chloride on photosynthetic physiology and wax content of cotton leaves. Chinese J Pest Sci. 2017;19:393397.

7. Deng XX, Jiang HL, Peng J, Zhou TT, Meng XG, Wang J, Wang JG. The effect of DPC dosage on physiology of cotton during flowering and bollsetting period. 2013;31:1-5.

8. Dong ZQ, He ZP, Zhai XJ. Studies of DPC (mepiquat) inhibition on Verticillium dahliae Kleb. infected cotton and the mechanism of it's action. Acta Gosaypii Siniea. 2000;12:77-80.

9. Gao HY, H, Khan A, Xia J, Hao XZ, Wang FY, Luo HH. Moderate drip irrigation level with low mepiquat chloride application increases cotton lint yield by improving leaf photosynthetic rate and reproductive organ biomass accumulation in arid region. Agronomy. 2019;9:834.

10. Hao DJ, Lu JW, Yin L. Toxicity of three biopesticides and their effect on detoxification enzyme activity of Corythucha ciliata. Scientia Silvae Sinicae. 2012;48:86-91.

11. Hu HY, Li X. Effect of mixed application of growth regulators and fertilizers on the growth, cold-resistance and physiology of turfgrass Zoysia matrella in wintering period. Chinese Journal of Eco-Agriculture, Nov. 2009;17:1099-1105.

12. Hullé M, Chaubet B, Turpeau E, Simon J. Encyclop'Aphid: a website on aphids and their natural enemies. Entomol. Gen. 2020;40:97-101.

13. Hussain N, Anwar A, Yasmeen A, Arif M, Naz S, Bibi M, Iqbal J, Qadir I, Salim MN, Latif S. Resource use efficiency of cotton in improved vs conventional planting geometry with exogenous application of bio-stimulant and synthetic growth retardant. Brazilian Journal of Biology. 2020.

14. Ibrahim G. Effect of plant growth regulators on agronomic characteristics, lint quality, pests, and predators in cotton. J Plant Growth Regulation. 2009;28: 147-153.

15. Jacobson R, Croft P. Strategies for the control of Aphis gossypii Glover (Hom.: Aphididae) with Aphidius colemani Viereck (Hym.: Braconidae) in protected cucumbers. Biocontrol Sci. Tech. 1998;8:377-387.

16. Juscelina Arcanjo dos Santos, Sylvana Naomi Matsumoto, Paulo André Trazzi, Paula Acácia Silva Ramos, Luan Santos de Oliveira, Otavio Camargo Campoe. Morphophysiological changes by mepiquat chloride application in Eucalyptus clones. Trees, 2020,:1-10.

17. Kamran M, Ahmad I, Wang HQ, Wu XR, Xu J, Liu TN, Ding RX, Han QF. Mepiquat chloride application increases lodging resistance of maize by enhancing stem physical strength and lignin biosynthesis. Field Crops Research. 2018;224:148-159.

18. Kaur S, Singh K, Deol J S, Kaur Navjyot, Biles S P, Cothren J.T, Boman R K, Westerman R.L, Burton J D, Pedersen M K, Coble H.D, Fang S, Gao K, Hu W, Wang S, Chen B, Zhou Z, Kerby T A, Plant RE, Horrocks R.D, Kumar K A K, Patil B C, Chetti M.B, Mao L, Zhang L, Zhao X, Liu S, Werf W, Zhang S, Spiertz H, Li Z, Ming wei D, Xiao li T, Liu sheng D, Ming cai Z, Wei ming T, Zhao hu L, Mrunalini K, Rekha M.S, Niakan M, Habibi A, Rajni Deol J S, Brar A S, Ren X, Du M, Evers JB, Tian X, Siebert JD, Stewart AM, Singh K, Rathore P, Singh T, Brar ZS, Soares LCS, Raphael JPA; Carvalho HR, Chiavegato EJ, Neto DD, Stewart AM, Edmisten KL, Wells R, Thomas WE, Everman WJ; Collins JR; Koger CH, Wilcut JW, Wang L, Mua C, Dua M, Chena Y, Tiana X, Zhanga M, Lia Z, Zhao D, Oosterhuis DM. Effect of plant growth regulators and defoliants on growth and productivity of american cotton (Gossypium hirsutum L.). Agricultural Research Journal. 2021;58:650-656.

19. Leal AJF, Piati GL, Leite RC, Zanella MS, Osorio CRWS, Lima SF. Nitrogen and mepiquat chloride can affect fiber quality and cotton yield. Revista Brasileira de Engenharia Agrícola e Ambiental-Agriambi. 2020;24:238-243.

20. Li L. Experimental guidance of plant physiology module, Beijing: Science Press. 2009.

21. Liang FB, Yang CX, Sui LL, Xu SZ, Yao HS, Zhang WF. Flumetralin and dimethyl piperidinium chloride alter light distribution in cotton canopies by optimizing the spatial configuration of leaves and bolls. Journal of Integrative Agriculture. 2020;19:1777-1788.

22. Liang XN, Liu FH, Zhang NG, Huang YS, Zhang SW, Zeng XC, Liu NW. Study on the yield-increasing and fiber-qualifying mechanism of compound regulators for ramie. 1999;21:32-36.

23. Liao BP, Ren XM, Du MW, Eneji AE, Tian XL, Li ZH. Multiple applications of mepiquat chloride enhanced development of plant-wide fruits from square initiation to boll opening in cotton. Crop Science. 2021;61:2733-2744.

24. Liu YT, Xu AY, Duan W, Wang P, Liu SL. Effects of mepiquat chloride, paclobutrazol and chlorocholine chloride on physiological characteristics of sunflower. Chinese Journal of Oil Crop Sciences. 2018;40:241-246.

25. Ma LH, Pen SL, Li SH. Effect of mepiquat chloride on the growth and development of Helicoverpa armigera. China Cotton. 1994;21:16.

26. Mao LL, Zhang LZ, Sun XZ, Werf W van der, Evers JB, Zhao XH, Zhang SP, Song XL, Li ZH. Use of the beta growth function to quantitatively characterize the effects of plant density and a growth regulator on growth and biomass partitioning in cotton. Field Crops Research.

$2018 ; 224: 28-36$. 
27. Mutunga JM, Anderson TD, Craft DT, Gross AD, Swale DR, Tong F, Wong DM, Carlier PR, Bloomquist JR. Carbamate and pyrethroid resistance in the akron strain of Anopheles gambiae. Pestic Biochem Physiol. 2015;121:116-121.

28. Nie LX, Jiang XY, Wu SH, Li JH, Wang Y, Ge DQ. Effects of different growth regulators on physiologic and yield in new species of the high yield maize. Journal of Shandong Agricultural University (Natural Science). 2010;41: 216-220.

29. Nóbrega LB, Vieira DJ, Beltrão NEM, Azevedo DMP, Oliveira JN. Effect of the growth regulator mepiquat chloride on herbaceous cotton crop in the Paraíba hinterland. (In Portuguese, with English abstract.). Rev. Bras. Ol. Fibros. 1999;3:89-92.

30. Nuti RC, Viator RP, Casteel SN, Edmisten KL, Wells R. Effect of planting date, mepiquat chloride, and glyphosate application to glyphosateresistant cotton. Agron. J. 2006;98:1627-1633.

31. Qiu LH, Chen RF, Luo HM, Fan YG, Huang X, Liu JX, Xiong FQ, Zhou HW, Gan CK, Wu JM, Li YR. Effects of exogenous GA 3 and DPC treatments on levels of endogenous hormone and expression of key gibberellin biosynthesis pathway genes during stem elongation in sugarcane. Sugar Tech. 2019;21:936-948.

32. Qu HL, Zhang JH, Ma WJ. Effect of chemical control on development and damage of Helicoverpa armigera (Hübner). Xinjiang Agricultural Sciences. 2008;45: 1142-1146.

33. Rademacher W. Growth retardants: Effects on gibberellins biosynthesis and others metabolic pathways. Annu. Rev. Plant Physiol. Plant Mol. Biol. 2000;51:501-531.

34. Ren XX, Wang G, Zuo YM, Wang KY, Wang J. The toxicity and effects of sublethal doses on detoxifying enzymes of clothianidin to Myzus persicae (Sulzer) (Hemiptera: Aphididae). Acta Entomologica Sinica. 2011;54:299-305.

35. Schaefer C, Nichols B, Collins G, Whitaker J, Bednarz C, Main C, Ritchie G. Cotton maturity determination through vertical mapping. Crop Sci. 2017;57:62-70.

36. Shu CE, Cao YP, Bao LX, Cao CY. The effects of pix treated cotton plant on the damage and reproduction of the carmine spider mite [Tetranychus cinnabarinus (Boisduval) ]. 1996;12:24-28.

37. Tung SA, Huang Y, Ali S, Hafeez A, Shah AN, Ma XL, Ahmad S, Chattha MS, Liu AD, Liu JH, Zhang Z, Yang GZ. Mepiquat chloride effects on potassium acquisition and functional leaf physiology as well as lint yield in highly dense late-sown cotton. Industrial Crops and Products. 2019;129:142-155.

38. Wang L, Yin Y, Wang LF, Wang ML, Zhao M, Tian Y, Li YF. Transcriptome profiling of the elongating internode of cotton (Gossypium hirsutum L.) seedlings in response to mepiquat chloride. Frontiers in Plant Science. 2019;10:1751.

39. Wang L, Mu C, Du MW, Chen Y, Tian XL, Zhang MC, Li ZH. The effect of mepiquat chloride on elongation of cotton (Gossypium hirsutum L.) internode is associated with low concentration of gibberellic acid. Plant Science. 2014;225:15-23.

40. Wang N, Wang XR, Shi JB, Liu XH, Xu QH, Zhou H, Song MZ, Yan GT. Mepiquat chloride-priming induced salt tolerance during seed germination of cotton (Gossypium hirsutum $\mathrm{L}$.) through regulating water transport and $\mathrm{K}^{+} / \mathrm{Na}^{+}$homeostasis. Environmental and Experimental Botany. 2019;159:168-178.

41. Wang N, Wang XR, Zhang HH, Liu XH, Shi JB, Dong Q, Xu QH, Gui H P, Song MZ, Yan GT. Early ABA-stimulated maintenance of Cl ${ }^{-}$ homeostasis by mepiquat chloride priming confers salt tolerance in cotton seeds. The Crop Journal. 2020. https://doi.org/10.1016/j.cj.2020.08.004.

42. Wang Y. 2011. Study of activity and biological effects and biochemical mechanisms of Spirotetramat to Aphis gossypii.

43. Wu Q, Du MW, Wu J, Wang N, Wang BM, Li FJ, Tian XL, Li ZH. Mepiquat chloride promotes cotton lateral root formation by modulating plant hormone homeostasis. BMC Plant Biology. 2019;19:573.

44. Xu FL, Luo LJ Gao CH. Inducing effects of plant growth regulators on the chilling resistance of sweet pepper (Capsicum annuum). Chinese Journal of Pesticide Science. 2011;13:33-39.

45. Xuan WY, Zhang T, Huang YL, Feng Z, Lin XH. DPC's impact on the growth and development of peanut. Journal of Guangxi Agriculture. 2010;25: $16-19,36$.

46. Yan W, Du MW, Zhao WC, Li F, Wang XR, Eneji AE, Yang FQ, Huang J, Meng L, Qi HK, Xue GJ, Xu DY, Tian XL, Li ZH. Relationships between plant architecture traits and cotton yield within the plant height range of $80-120 \mathrm{~cm}$ desired for mechanical harvesting in the Yellow River Valley of China. Agronomy. 2019;9:587-587.

47. Yin J, Feng HL, Li KB, Cao YZ. Effects of host plants on the activities of some detoxification enzymes and protective enzymes in the meadow moth. Plant Protection. 2012;38:35-39.

48. Zhang J, Zhang YS, Xing JP, Yu HY, Zhang R, Chen YY, Zhang DL, Yin P, Tian XL, Wang Q, Duan LS, Zhang MC, Peters RJ, Li ZH. Introducing selective agrochemical manipulation of gibberellin metabolism into a cereal crop. Nature Plants. 2020;6:67-72.

49. Zhang X, Rui QZ, Li Y, Chen Y, Zhang XL, Chen DH, Song MZ. Architecture of stem and branch affects yield formation in short season cotton. Journal of Integrative Agriculture. 2020;19:680-689.

50. Zhao D, Oosterhuis DM. Physiological, growth, and yield responses of cotton to mepplus and mepiquat chloride. p. 599-602. In Proc. Beltwide Cotton Conf., Orlando, FL 3-7 Jan. 1999. Natl. Cotton Counc. Am., Memphis, TN. 
51. Zhao D, Oosterhuis DM. Pix plus and mepiquat chloride effects on physiology, growth, and yield of field-grown cotton. J. Plant Growth Regul. 2000;19:415-422.

52. Zhong L, Wang QL, Cui JL, Li WJ, Wang JG. Effects of DPC application to cotton on enzyme activity in Aphis gossypii. Journal of Shihezi University: Natural Science. 2017;35:195-200.

53. Zhou MY, Li YB, Cui Q, Abidallha EHMA, Chen Y, Chen DH. Square insecticidal protein concentration relate to its biomass in Bt cotton. Agronomy Journal. 2019;111:467-472.

54. Zhou YG, Wang JG, Ma TW, He ZM<bi><</bi> Influences of different DPC treatments on physiological and biochemical characteristics of cotton. Xinjiang Agricultural Sciences. 2010;47:1142-1146.

55. Zhou YG, Wang JG, Ma TW, He ZM. Effects of mepiquat chloride (DPC) on species reproduction of Aphis gossypii Glover. Acta Agriculturae Boreali-occidentalis Sinica. 2011;20:199-202.

56. Zummo GR, Benedict JH, Segers JC. Effect of the plant growth regulator mepiquat chloride on host plant resistance in cotton to bollworm (Lepidoptera: Noctuidae). Journal of Economic Entomology. 1984;77:922-924.

57. Zummo GR, Benedict JH, Segers JC. No-Choice study of plant-insect interactions for Heliothis zea (Boddie) (Lepidoptera: Noctuidae) on selected cottons. Environmental Entomology. 1983;12:1833-1836.

\section{Figures}
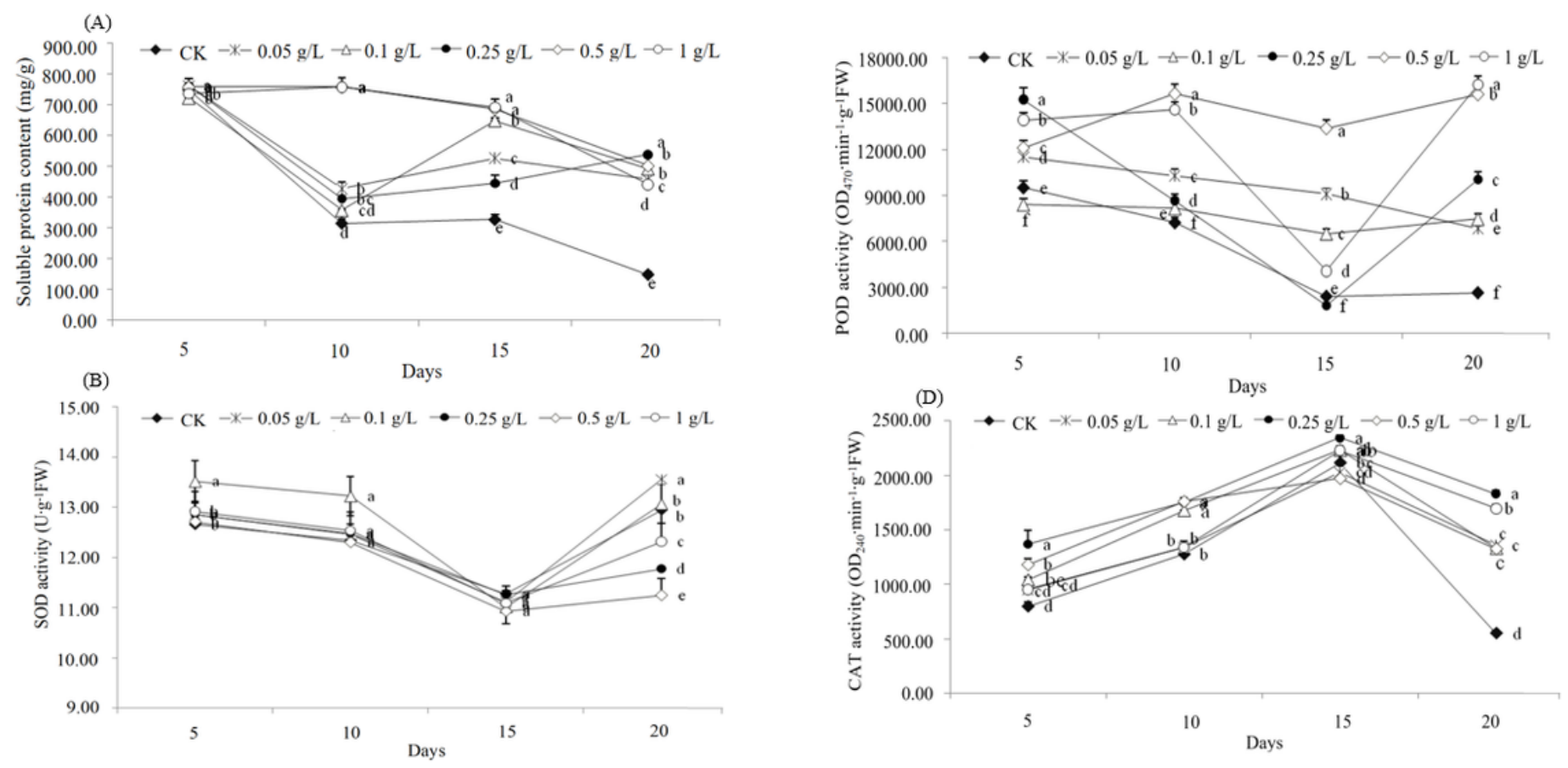

Figure 1

The effect of DPC treatment on the protective enzyme activity in cotton. (A) Soluble protein contents. (B) SOD activity. (C) POD activity. (D) CAT activity. Lower-case letters indicate the significant differences for the control (CK) and the five DPC treatments at different concentrations from 5 to 20 days after DPC application. 

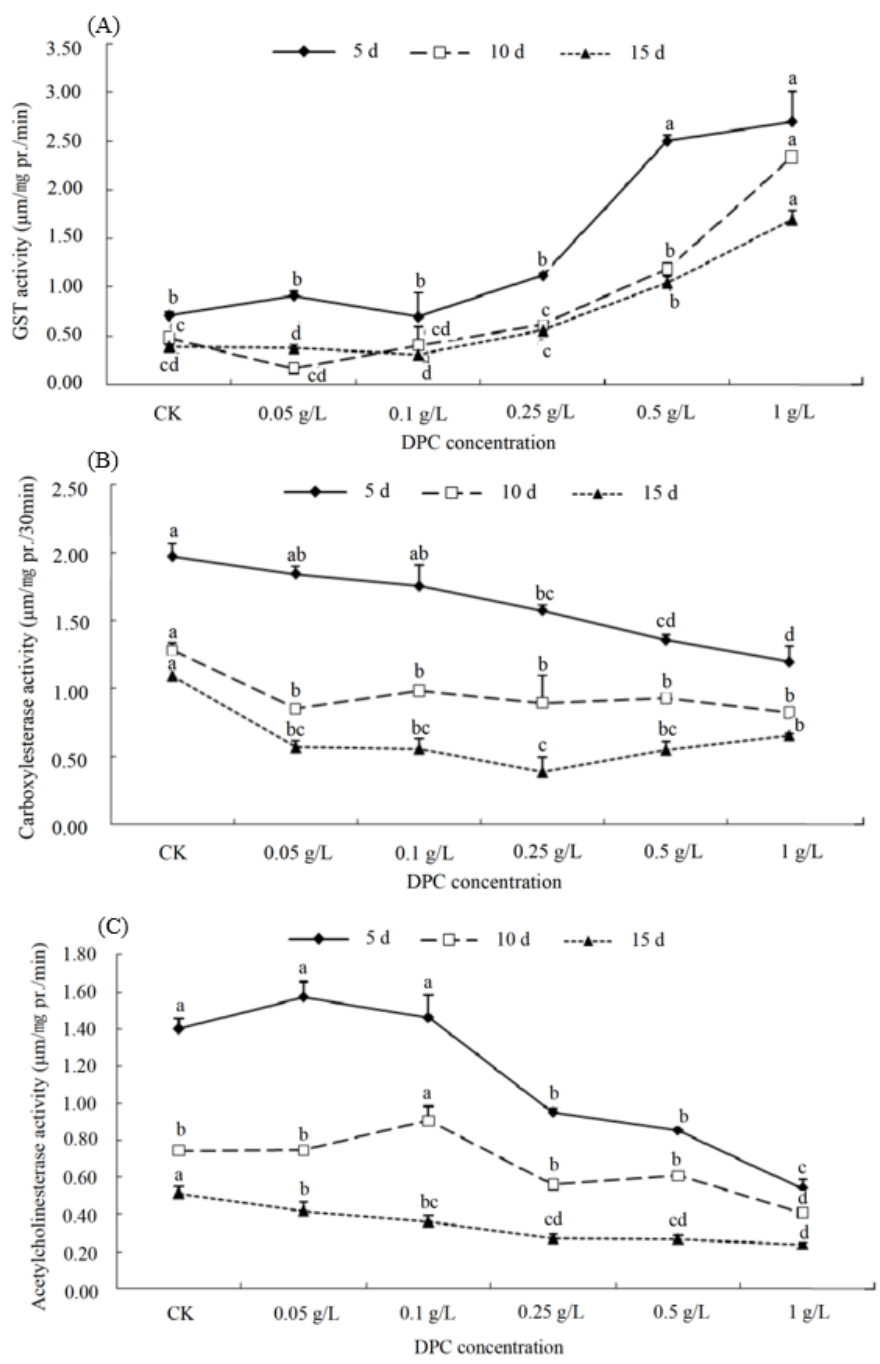

Figure 2

Effects of spraying DPC on detoxification enzyme activity in cotton aphids. (A) GST activity. (B) Carboxylesterase activity. (C) Acetylcholinesterase activity. Lower-case letters indicate the significant differences between the control (CK) and the five DPC concentrations after 5,10 , and 15 days of feeding. 

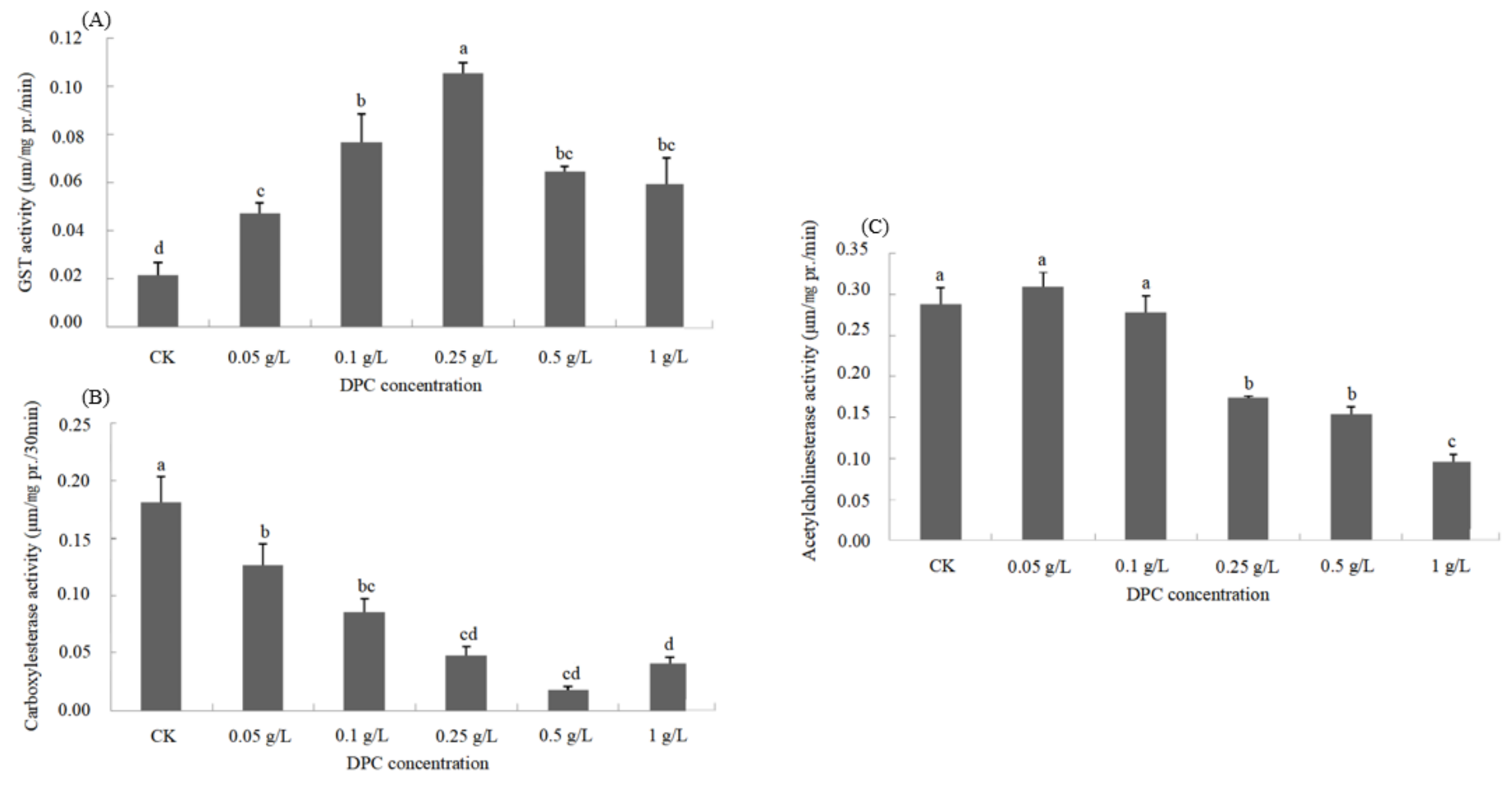

\section{Figure 3}

Effect of DPC leaching solution treatment on detoxifying enzymes in cotton aphids. (A) GTS activities. (B) Carboxylesterase activities. (C) Acetylcholinesterase activities. Lower-case letters indicate the significant differences in aphids between the control (CK) and the five DPC treatments. 